\title{
Farklı Akademik Başarıya Sahip Matematik Öğretmeni Adaylarının Gerçekleştirdikleri Klinik Mülakatların Karşılaştırılması*
}

\section{Aytuğ ÖZALTUN ÇELİK ${ }^{1}$, Esra BUKOVA GÜZEL ${ }^{2}$}

Öz: $\mathrm{Bu}$ çalışmanın amacı, farklı akademik başarıya sahip matematik öğretmeni adaylarının gerçekleştirdikleri klinik mülakatları karşılaştırmaktır. İç içe geçmiş çoklu durum çalışması desenine dayandırılan çalışmanın katılımcılarını tabakalı amaçlı örneklemeye dayalı olarak seçilen on lise matematik öğretmeni adayı oluşturmuştur. Öğretmen adaylarının seçiminde altı döneme ait akademik not ortalamalarından yararlanılmıştır. On öğretmen adayından beşi sınıftaki en yükssek akademik ortalamaya sahip iken diğer beşi en düşük akademik ortalamaya sahiptir. Çalışmanın verileri öğretmen adaylarının gerçekleştirdiği klinik mülakat uygulamalarının video kayıtlarından derlenmiştir. Her bir klinik mülakat transkript edilmiş ve transkript metinleri ögretmen adaylarının sordukları sorular doğrultusunda analiz edilmiştir. Düşük akademik başarı ortalamasına sahip matematik öğretmeni adayları klinik mülakatları boyunca genellikle yönlendirici sorulardan yararlanırken, yüksek akademik başarı düzeyindeki öğretmen adayları düşüncelere odaklı sorular sormuşlardır. Sonuçlara dayalı olarak, öğretmen adaylarının klinik mülakat öncesinde kavramsal analiz yapmalarının ve bu kavramsal analizlerine dayalı klinik mülakatlar gerçekleştirmelerinin matematik öğretimi için önemli olduğu düşünülmektedir.

Anahtar Kelimeler: Akademik başarı, klinik mülakat, matematik öğretmeni adayı, öğrenci düşüncelerini anlama

\footnotetext{
1 Arş. Gör. Dr. Pamukkale Üniversitesi, Eğitim Fakültesi, Matematik Eğitimi Anabilim Dalı, email:aytug.deu@gmail.com Orcid No: 0000-0003-1310-3247

2 Prof. Dr, Dokuz Eylül Üniversitesi, Buca Eğitim Fakültesi, Matematik Eğitimi Anabilim Dalı, email: esra.bukova@gmail.com, Orcid No: 0000-0001-7571-1374

* Bu çalışma 27. Uluslararası Eğitim Bilimleri Kongresi’nde sunulan bildirinin genişletilmiş halidir.
}

Gönderim:04.07.2019 Kabul:31.08.2019 $\quad$ Yayın: 02.01.2020




\section{Comparing the Clinical Interviews Conducted by the Prospective Mathematics}

\section{Teachers Having Different Academic Achievement}

Abstract: The purpose of this study is to compare the clinical interviews conducted by the prospective mathematics teachers with different academic achievements. The participants of this embedded multiple case study were ten prospective mathematics teachers selected by stratified purposeful sample. The participants' selection was based on their six semester grade averages. Five had the highest academic averages while the others had the lowest academic averages. The data were compiled from the video recordings of the clinical interview applications performed by the student teachers. Each clinical interview was transcribed and the transcripts were analyzed in the context of questions asked by the prospective teachers. During clinical interviews, while the prospective mathematics teachers with low academic averages used funneling questions, the participants with high academic averages asked the questions focusing on students thinking. Based on the results, it is thought that it is of significant for the prospective teachers to be asked to make conceptual analysis related to the concepts prior to the clinical interview and conduct clinical interviews based on their conceptual analysis.

Keywords: Academic achievement, clinical interview, prospective mathematics teachers and understanding student thinking.

\section{Giriș}

Ulusal Matematik Öğretmenleri Konseyi (National Council of Teachers of Mathematics [NCTM]) raporunda (2000) okul matematiğinin altı temel prensibinden biri olarak ele alınan değerlendirme süreçlerinin matematiğin öğrenilmesini desteklediği ve hem öğretmenler hem de öğrenciler için önemli bilgiler sunduğu vurgulanmıştır. Sunduğu bilgilerle öğretime yön veren değerlendirme süreci içeriğine ve gerçekleştirilme yaklaşımlarına göre değişiklik göstermektedir. Öğretime yönelik etkili dönütler verebilmesi için değerlendirme yaklaşımlarının öğrenciler ve öğrenme süreci ile ilgili pek çok kanıtı ortaya çıkarabilmesi önemlidir. Matematik için Ortak Temel Eyalet Standartları [The Common Core State Standards for Mathematics (CCSSM)] (2010) öğrencilerin matematiksel anlamalarının ve işlemsel becerilerinin onların sadece anlayıp anlamadıklarını ortaya çıkaracak etkinliklerin ötesinde nasıl düşündüklerine odaklanan ve gerekçelendirmeler yapmalarını isteyen zengin içerikli etkinliklerle 
değerlendirilebileceğine değinmiştir. İçerik açısından zengin alternatif değerlendirme etkinlikleri matematiksel kavramların ilgili olduğu tüm fikirleri içerecek ve bu fikirlerle ilişkili olarak neden, nasıl gibi sorularla öğrencilerin kavramlara ilişkin zihinsel süreçlerini ortaya çıkarabilecek şekilde kapsamlı olmalıdır. Öğrencilerin matematiksel anlamalarını değerlendirmede sonuç odaklı soruları içeren geleneksel değerlendirme yaklaşımları yeterli olmamakta ve daha ayrıntılı bilgilere ulaşılmasını sağlayan ve sonuç yerine sürece odaklanan alternatif değerlendirme yaklaşımlarına ihtiyaç duyulmaktadır (Ginsburg, Jacobs, \& Lopez, 1993; Kazemi, Gibbons, Lomax, \& Franke, 2016). Daha açık bir şekilde, geleneksel değerlendirme yaklaşımları öğrencilerin bilgilerini, düşüncelerini ve temel fikirlerini yok saymakta ve matematik eğitiminde öğrencilerin bilgi ve öğrenmeleriyle ilgili çok az bilgi sunarak eğitim sürecine yol gösterici olmaktan daha çok soruna yol açmaktadır (Ginsburg, 1997). Sadece öğrencilerin neyi öğrenip öğrenemediğine odaklanan bu değerlendirme süreçleriyle, matematik öğrencilerden bağımsız olarak ele alındığı ve öğrenme süreçleri derinlemesine incelenmediği için öğretimin etkililiğini arttıracak gerekli düzeltmeler ve revizyonlar belirlenememektedir. Dolayısıyla öğrencilerin eksik anlamaları üzerine sonraki öğretim aşamalarına geçiş yapılmaktadır. Buna karşın, alternatif değerlendirme yaklaşımları, öğrenenler ile ilgili daha kapsamlı bir resim ortaya çıkarılmasını sağlamakta ve öğrenmeyle ile ilgili çıkarımları zorlaştıran geleneksel değerlendirme yaklaşımlarından daha gerçekçi bilgiler sunmaktadır (Adams, 1998). Gelişim psikolojisi literatüründe, çocuğun standartlaştırılmamış ve esnek bir şekilde sorgulanmasını gerektiren klinik mülakat yöntemi, matematiksel düşünmenin incelenmesi için temel araştırma aracı olarak ortaya çıkmış (Ginsburg, Jacobs, \& Lopez, 1993) ve matematik eğitiminde yaygın olarak kullanılan alternatif değerlendirme yaklaşımlarından biri olmuştur.

Çocukların düşüncelerini anlama üzerine çalışan Piaget (1976) sorular sormaksızın sadece gözlem yaparak çocuğu tanımanın ve eylemlerinin altında yatan nedenleri ortaya çıkarmanın zor olduğu ifade etmiştir. Bu sebeple test yöntemlerinde ve doğrudan gözlemlemede en uygun olan yaklaşımları bir araya getirerek klinik mülakat yöntemini geliştirmiştir. Bir başka deyişle, çocukların akıl yürütme biçimlerini ve işlevlerini anlamak için klinik mülakatı ortaya atmış (Mojica, 2010) ve klinik mülakatı öğrencilerin belirli bir konu ile ilgili kavram yanılgılarının altında yatan nedenleri anlama imkanı sunmayan standart testlere alternatif olarak kullanmıştır (Pablopulos \& Carolina, 
2015). Hunting (1997) matematik eğitimi kapsamında klinik mülakatı öğrencilerin düşüncelerini ve matematiksel öğrenmelerini değerlendirmenin alternatif bir yolu olarak ifade etmiştir. Klinik mülakat, bir bireyin zihinsel süreçleri ile ilgili veri toplamayı ve analiz etmeyi sağlayarak bireyin düşüncelerindeki gizli yapıları ve süreçleri ortaya çıkarmaya imkân vermektedir (Clement, 2000; Confrey, 2006; Koichu \& Harel, 2007). Dolayısıyla, öğrencilerin matematiksel kavramlara ilişkin gerçekte ne gibi anlamalar oluşturduklarını belirleyebilmede etkili bir değerlendirme yaklaşımı olarak kullanılmaktadır.

Klinik mülakatta öğrenciler, ilgili kavrama ilişkin düşüncelerini anlamaya imkan veren, bir etkinlik ya da soru üzerinde çalışmaktadırlar (Ernest, 1993; Taylan, 2018). Klinik mülakatın üzerine yapılandırıldığı bu soru ya da etkinlik bir gerçek yaşam durumunu içerebilir. Bu tür gerçek yaşam durumları öğrencilerin deneyimledikleri ya da fikir yürütebilecekleri durumlar olması sebebiyle rahat bir şekilde konuşabilmelerini sağlamakta ve kavramlara ilişkin düşüncelerini açığa çıkarmada etkili olabilmektedir. Klinik mülakatların sonucu, öğrencilerin belirli kavramları nasıl anladıklarını ve hangi alternatif öğrenme yaklaşımlarına ihtiyaç duyduklarını ortaya çıkarmakta ve öğrencilerin ulaştıkları sonuçlar yerine süreç boyunca oluşturdukları yapıların ve ilişskilendirdikleri kavramların ayrıntılı bir şekilde belirlenmesine imkan vererek öğretimin geliştirilmesine destek vermektedir (Bowman, Donovan, \& Burns, 2000; Engelhardt, Corpuz, Ozimek, \& Rebello, 2003; Ginsburg, 1997).

Matematiksel kavramları öğrencilerin kendi zihinsel eylemleriyle oluşturmalarını destekleyen ortamlar olarak ifade edebileceğimiz matematiksel öğretme süreçlerini destekleyen klinik mülakatların öğretmenler tarafından etkili bir şekilde gerçekleştirilmesini sağlayan çeşitli faktörler bulunmaktadır. Fuchs ve Czarnocha (2016) mülakatı gerçekleştiren kişinin güçlü mülakat becerilerine ve iyi bir alan öğretimi bilgisine sahip olması gerektiğini ifade etmektedirler. Benzer şekilde, Heirdsfield (2002) öğretmenlerin klinik mülakatlarını alan ve alan öğretimi bilgilerine dayanan bir çerçeveye yerleştirmeleri gerektiğini dile getirmektedir. Bunların yanı sıra, bu süreci uygulamada en belirleyici olan faktörlerden bir diğeri de klinik mülakatı gerçekleştiren kişinin soru sorma becerisidir.

\section{Klinik Mülakat ve Soru Sorma}


Klinik mülakatın, öğrencinin bilişsel süreçlerini keşfetmek, ikincisi bilişsel süreçlerinin temellerini tanımlamak ve üçüncüsü öğrencinin yeterliliğini belirlemek olarak ifade edilen üç amacı (Ginsburg, 1981) doğrultusunda, mülakatın gerçekleştirildiği duruma ya da kavrama yönelik öğrencinin verdiği yanıtlar tüm mülakat boyunca ayrıntılı ele alınmakta ve neleri nasıl düşündüğü ve düşüncelerinin kaynağının neler olduğu ayrıntılı sorgulanmaktadır. Bu amaçları gerçekleştirebilmek için mülakatı yapan kişi önceden belirlediği standart sorular yerine o an öğrencinin yanıtına göre sorular sorarak mülakatı ilerletmektedir (Taylan, 2018). Bu sebeple, klinik mülakat uygulaması soru sorma becerilerinin uygulanmasını içererek mülakatı gerçekleştiren kişiyi soru sormaya zorlayan bir süreçtir (Moyer \& Milewicz, 2002). Dolayısıyla, öğretmenlerin, öğrencilerin ilgili kavram ya da konuyla ilgili önceki fikirlerini açığa çıkararak öğrencilerin anlamalarını geliştirmek için yararlandıkları soru sorma sürecinin (Weiland, Hudson, \& Amador, 2014) klinik mülakata yön verdiği söylenebilir. Klinik mülakat sırasında mülakatı yapan kişinin kendi düşüncelerine yönlendiren sorular yerine "Neden böyle düşündün?”, "Nasıl bir yol izlersin?”, "Buna nasıl karar verdin?”, "Bu söylediğin ne anlama geliyor?”, “Bu düşüncenin/fikrinin gerekçesi nedir?” gibi doğrudan öğrencilerin düşüncelerine odaklanan sorular sorması, süreç boyunca sorulan sorulara ilişkin öğrenci düşüncelerini anlamaya çalışması sebebiyle, amaca ulaşmada en belirleyici etken olarak düşünülmektedir. Buna ek olarak, klinik mülakat sürecinde öğrencilerin sorulara yanıt verirken yüksek sesle düşünmelerinin istenmesi ve fikirleri hakkında yorum yapmalarının desteklenmesi önemli bir etkendir (Ashlock, 2006). Diğer yönden, klinik mülakat uygulamaları yapmak soru sorma becerisini de geliştirmektedir. Klinik mülakatta, öğretmenler ya da öğretmen adayları öğrencilerle etkileşimlerden kendi performanslarını inceleyerek ve mülakatlarda kullandıkları sorular üzerine yansıtmalar yaparak, sordukları soruların gerekçeleri üzerine düşünmekte ve bu yansıtma sürecini daha iyi soru sorma stratejisi geliştirmek için kullanmaktadırlar (Moyer \& Milewicz, 2002). Bu sebeple matematiksel öğrenmeyi öğrenci düşünceleriyle ilişkilendiren, değerlendirme süreçlerinde öğrencilerin düşüncelerini göz önüne alan ve etkili sorular sorabilen öğretmenler yetiştirebilmek için öğretmen eğitiminde klinik mülakata değinilmesi gerekliliği ortaya çıkmaktadır.

\section{Öğretmen Eğitiminde Klinik Mülakat}


Öğretmen eğitiminde derinlemesine değerlendirme imkanı veren klinik mülakat uygulamalarına odaklanılması ve bu yönde çalışmalar yapılması matematik öğretme süreçlerinin niteliğini arttırmada önemlidir. Klinik mülakat süreci öğretmen adaylarının alan ve alan öğretimi bilgileriyle ilişkili olarak şekillendiği için uygulama aşaması bu bilgilerini güçlendirmelerini sağlayacaktır. Klinik mülakat yapmaya hazırlanan öğretmen adayları ilk olarak ilgili kavramlara ilişkin bilgilerini gözden geçirmek ve derinleştirmek için çalışmalar yapma gereksinimi duyacak ve bu sayede alan bilgilerini geliştirme imkânı bulacaklardır. Bu süreçte sürekli olarak öğrenci düşüncelerini ve anlamlarına odaklanıldığı için öğrenci düşüncelerine yönelik farkındalıklarının (An \& Wu, 2012) gelişimine de katkı sağlayacaktır. Jenkins (2010) klinik mülakatın öğrencilerin matematiksel düşünceleri ile ilgili bilgilerini geliştirmelerini desteklediği ve öğrencilerin matematiği nasıl anladıklarına yönelik etkili bir pencere sunduğu gerekçesiyle öğretmen adaylarının matematiği öğretme dersleri kapsamında klinik mülakat uygulamalarına firsat verilmesi gerektiğini ifade etmektedir. Ayrıca öğretmen adaylarının gerçekleştirdikleri klinik mülakatlar ile sınıf durumlarının belirsizliklerini deneyimleme imkanı yakalamaları (Moyer \& Milewicz, 2002) onların ileri dönemlerdeki öğretim süreçlerine olumlu bir şekilde yansıyacaktır. Van den Kieboom, Magiera ve Moyer (2017) öğretmen adaylarının klinik mülakat yaparken öğrenci düşünceleriyle ilgilendiklerini, öğrenci düşüncelerini yorumladıklarını ve anlamlandırdıklarını ifade etmektedirler. Ayrıca, öğrencilerin olası hatalarını ve zorluklarını belirleyebilmekte ve klinik mülakat sürecine dayalı olarak öğretimlerini nasıl gerçekleştireceklerine ilişkin fikirler üretmektedirler (Haydar, 2017).

Öncelikli olarak öğretmen adaylarının klinik mülakatın ne olduğu, nasıl yürütüldüğü ve matematik öğretimi için neden önemli olduğu gibi sorulara yanıt verebilmeleri önemlidir. Bunun yanı sıra uygulama aşamasında da öğretmen adaylarının etkili olabilmesi için farklı yönlerden gelişimlerinin desteklenmesi sağlanmalıdır. Klinik mülakatta öğrencilerin bilişsel süreçlerinin ortaya çıkarılması amaçladığından, öncelikle mülakatı gerçekleştirecek öğretmen adaylarının ilgili kavramlara ilişkin bilgileri ve teorik alt yapıları güçlü olmalıdır. Ginsburg (1997) klinik mülakatın öğrenci zihnindekini ortaya çıkarmayı amaçladığı gerekçesiyle mülakatı yapan kişilerin süreç boyunca aktif ve yaratıcı olmalarını ve risk almalarını gerektirdiğini ifade etmektedir. Benzer şekilde, Haydar (2017) klinik mülakatı gerçekleştirirken, öğrencilerin davranışlarına anlık 
geribildirim verebilme becerisine sahip olmanın deneyimi ve güçlü içerik bilgisini gerektirdiğini vurgulamaktadır. Bu sebeple öğretmen adaylarının aldıkları eğitime dayalı oluşturdukları mevcut bilgilerinin ve başarı durumlarının klinik mülakat sürecini etkilediği düşünülmektedir. Bir başka ifadeyle, öğretmen adaylarının etkili klinik mülakatlar gerçekleştirebilmeleri sadece klinik mülakatın ne olduğunu ve nasıl yürütüldüğünü bilmelerinin ötesinde, hem ilgili kavrama ilişkin alan ve alan öğretimi bilgilerine hem de uygulama sürecindeki öğrencilerle etkileşimlerine dayanmaktadır. Hunting (1997) de gelişmiş bir mülakat becerisi için alan öğretimi bilgisinin gerekli olduğunu ifade etmektedir. Sözü edilen fikirler doğrultusunda, çalışmada öğretmen adaylarının alan ve alan öğretimi bilgilerinin klinik mülakat yapma sürecine nasıl yansıdığı araştırılmak istenmiştir. Ek olarak, öğretmen adaylarının etkili klinik mülakatlar yapmaları için ne gibi ihtiyaçlarının olduğunun belirlenmesi ve bu doğrultuda öğretmen eğitiminde yer verilmesi gereken içeriklere yönelik dönütler sunulması hedeflenmiştir. Çalışmada, alan ve alan öğretimi bilgisine karşılık olarak öğretmen adaylarının akademik not ortalamaları göz önüne alınmış ve akademik not ortalamaları akademik başarı düzeyi olarak ifade edilmiştir. Öğretmen adaylarının başarı düzeylerinin klinik mülakat sürecine nasıl yansıdığını belirlemenin klinik mülakat ile alan ve alan öğretimi bilgisinin ilişkisine yönelik kanıtlar sunacağı düşünülmüştür. Bu ilişkiyi daha iyi ortaya koyabilmek farklı başarı düzeylerindeki öğretmen adaylarının uygulamalarına odaklanmak ile mümkün olabilir. Ayrıca farkı akademik başarıdaki öğretmen adaylarının matematiksel kavramlara yönelik gerçekleştirdikleri klinik mülakatlarında farklılaşan hususların belirlenmesi matematik eğitimi derslerinde nelere odaklanılması gerekliliği yönünde fikir verecektir. Klinik mülakatlar sırasında öğretmen adaylarının düşüncelere odaklanıp odaklanmama yönündeki yaklaşımlarındaki farklılıkları klinik mülakatlar sırasında kullandıkları sorular yardımıyla ortaya çıkarmak mümkündür. Çünkü klinik mülakatta kullanılan sorular ve soru sorma yaklaşımları, sürecin yansıması olarak gözlemlenebileceği için, mülakatları değerlendirme fırsatı vermektedir. Bu motivasyon doğrultusunda çalışmanın amacı, yüksek ve düşük akademik başarı düzeyi gruplarındaki matematik öğretmeni adaylarının gerçekleştirdikleri klinik mülakatları, mülakatlar boyunca kullandıkları sorular açısından inceleyerek karşılaştırmaktır.

\section{Yöntem}




\section{Araştırmanın Deseni}

Yüksek ve düşük akademik başarı düzeyine sahip matematik öğretmeni adaylarının belirledikleri matematiksel kavramlara yönelik gerçekleştirdikleri klinik mülakatların derinlemesine incelenip karşılaştırılmasının amaçlandığ 1 bu çalışma, durum çalışması desenine dayandırılmıştır. Durum çalışmaları, özellikle değerlendirme süreçleri gibi birçok alanda kullanılan, araştırmacının bir durumu, sıklıkla da bir programı, olayı, eylemi, süreci ya da bir veya daha fazla bireyi derinlemesine analiz ettiği bir araştırma desenidir (Creswell, 2013). Çalışmada üçüncü sınıf on öğretmen adayının klinik mülakatı gerçekleştirme eylemleri derinlemesine analiz edildiği ve bu analizlere dayalı karşılaştırmalar yapıldığı için, çalışma iç içe geçmiş çoklu durum çalışması desenine dayalı yürütülmüştür. Düşük başarı düzeyindeki öğretmen adaylarının klinik mülakatları çalışmadaki bir durum iken, yüksek başarı düzeyindeki öğretmen adaylarının klinik mülakatları diğer durumdur. Her birim durum içerisindeki beşer öğretmen adayının klinik mülakatları ise analiz birimleri olarak alınmıştır.

\section{Katılımcılar}

Bu çalışmanın katılımcılarını Özel Öğretim Yöntemleri II dersini tamamlamış olan 3.sınıf on lise matematik öğretmeni adayı oluşturmaktadır. Bu dersi tamamlayan öğretmen adaylarının seçilmesinin nedeni ders kapsamında klinik mülakat uygulamalarına dahil olmuş olmaları ve bu sebeple klinik mülakata ve sürecine ilişkin bilgilerinin olmasıdır. Katılımcı öğretmen adayları tabakalı amaçlı örneklemeye dayalı olarak seçilmiştir. Her bir tabakanın homojen bir örnek oluşturduğu bu örneklemlerin seçilmesinin amacı, ortak bir temel oluşturmak yerine ortak analizler yardımıyla ana değişiklikleri belirleyerek gruplar arası karşılaştırmalar yapmaktır (Patton, 2002). Çalışmada farklı akademik başarı düzeylerinde olan öğretmen adaylarının klinik mülakatları karşılaştırıldığı için bu örnekleme yöntemine dayalı seçim yapılmıştır. Öğretmen adaylarının alan ve alan öğretimi bilgilerinin göstergesi akademik not ortalamaları olarak kabul edilmiş ve aynı dönemdeki tüm öğretmen adaylarının önceki altı döneme ait not ortalamaları dikkate alınarak en yüksek akademik not ortalamasına sahip beş öğretmen adayı ile en düşük akademik ortalamaya sahip beş öğretmen adayı belirlenmiştir. Birbirinden oldukça farklı iki başarı düzeyinde olan öğretmen adaylarının belirlenmesi, akademik başarının klinik mülakat sürecinde neden olabileceği farklılıkları 
daha iyi ortaya çıkarılabileceği düşüncesine dayandırılmış ve bu sebeple sadece yüksek ve düşük akademik başarı düzeyindeki öğretmen adayları katılımcı olarak seçilmiştir. Seçilen öğretmen adaylarının akademik not ortalamaları (bkz. Tablo 1) 100’lük sisteme göre ele alındığında, yüksek akademik başarı düzeyindeki öğretmen adaylarının notlarının ortalaması 85, düşük akademik başarı düzeyindeki öğretmen adaylarının notlarının ortalaması ise 64'tür. Aynı sınıf düzeyindeki tüm öğrencilerin notlarının dikkate alınmasıyla oluşturulan bu iki grubun temsil ettiği başarı düzeyleri arasındaki farklılığın bağıl değerlendirmenin uygulandığı bir sistemde kayda değer olduğu söylenebilir. Öğretmen adaylarının akademik not ortalamaları alan ve alan öğretimi bilgilerinin göstergesi olarak düşünüldüğünde de, klinik mülakat eylemlerinde farklılıklar için belirleyici olduğu düşünülmektedir.

Tablo 1. Öğretmen adaylarının akademik not ortalamaları

\begin{tabular}{cccc}
\hline \multirow{2}{*}{ Kategori } & Öğretmen & \multicolumn{2}{c}{ Akademik ortalama } \\
& aday1 & 4'lük sisteme göre & 100’lük sisteme göre \\
\hline \multirow{3}{*}{ Yüksek } & ÖA1 & 3.51 & 88.56 \\
akademik & ÖA2 & 3.44 & 86.93 \\
başar1 & ÖA3 & 3.34 & 84.60 \\
& ÖA4 & 3.28 & 83.20 \\
& ÖA5 & 3.14 & 79.93 \\
Düşük & ÖA6 & 2.56 & 66.86 \\
akademik & ÖA7 & 2.52 & 65.46 \\
başar1 & ÖA8 & 2.5 & 65 \\
& ÖA9 & 2.42 & 63.13 \\
& ÖA10 & 2.35 & 61.50 \\
\hline
\end{tabular}

\section{İşlem Basamakları}

Katılımcı öğretmen adayları Özel Öğretim Yöntemleri II dersinin içeriğinde matematiksel öğrenme süreçleriyle ilişkili olarak dönemin son iki haftası boyunca klinik mülakat üzerine çalışmalar yapmışlardır. Klinik mülakat uygulamaları matematik öğretmenleri için önemli olduğu gerekçesiyle Özel Öğretim Yöntemleri II dersinde bu içeriğe yer verilmiş ve içerik kapsamındaki hedefler şu şekilde olmuştur:

- Ölçmenin geleneksel amaçları yanında öğretim amaçlı rolünü fark eder.

- Öğrencinin ne bilip/bilmediği ile nasıl düşündüğü arasındaki farkı kavrar.

- Klinik mülakatı açıklayarak klinik mülakat ile kavram analizi arasındaki ilişkiyi yorumlar. 
Haftada iki ayrı gün ikişer ders saati olmak üzere toplam dört saat yürütülen ders kapsamında, öğretmen adayları ilk olarak klinik mülakatın ne olduğu, neden yapıldığı, nasıl yürütüleceği ve matematik eğitimi için öneminin ne olduğu ile ilgili bir makale (Hunting, 1997) okumuşlardır. İngilizce dilde yazılan bu makale Türkçe olarak öğretmen adaylarına verilmiştir. Makale okumalarına dayalı oluşturdukları klinik mülakata ilişkin fikirleri doğrultusunda sınıf tartışması gerçekleştirilmiştir. Sınıf tartışmasında öğretmen adaylarının klinik mülakatla ilgili düşüncelerini birbirleriyle paylaşmaları istenmiş ve böylelikle klinik mülakatı teorik olarak anlamlandırmalarına ortam hazırlanmıştır. Dersi gerçekleştiren öğretim üyesi sınıf tartışmaları sırasında klinik mülakatın uygulama sürecine ilişkin öğretmen adaylarının düşüncelerini sürekli olarak sorgulayarak temel fikirleri oluşturmaları ve öğretmen olarak bu süreci yorumlamaları için sınıf tartışmasını yönetmiştir. Sonrasında klinik mülakatın öğrencilerin kavramlarla ilgili neler bildiklerini ve düşündüklerini değerlendirmenin alternatif bir yolu olduğunu gösteren, bir on birinci sınıf öğrencisi ile ikinci dereceden fonksiyonlar üzerine gerçekleştirilen, klinik mülakat uygulaması sunulmuştur. Seçilen öğrencinin ikinci dereceden fonksiyonlara ilişkin öğretim sürecini tamamlamış olması bir kriter olarak belirlenmiştir. Bu klinik mülakatta öğrenciye " $f(x)=x^{2}+2 x-3$ nasıl bir fonksiyondur? $\mathrm{Bu}$ fonksiyonun grafiğini çizmek istesen nasıl bir yol izlersin?” sorusunu içeren bir klinik mülakat protokolü verilmiş ve bu soruyu yanıtlama sürecinde ikinci dereceden fonksiyonlara ilişkin düşünceleri ortaya çıkarılmaya çalışılmıştır. Kendini rahat hissedebileceği uygun bir ortamda gerçekleştirilen ve yaklaşık 75 dakika süren bu klinik mülakatın video kamera kaydının transkriptinden alınan kesitler öğretmen adaylarına verilmiş ve öğretmen adaylarının öğrenci düşüncelerine odaklı sorular içeren bu klinik mülakat kesitlerini araştırmacının yaklaşımları ve sorduğu sorular açısından yorumlamaları istenmiştir. $\mathrm{Bu}$ sayede öğretmen adaylarının öğrencilerin düşüncelerine odaklanan bir değerlendirme sürecinin nasıl gerçekleştirilebileceğine yönelik bir uygulama üzerine düşünmeleri sağlanmıştır. Bu süreç onların klinik mülakata ilişkin teorik olarak oluşturdukları fikirlerini güçlendirmek amacıyla gerçekleştirilmiştir. Öğretmen adayları kesitlerdeki araştırmacı yaklaşımları ile ilgili yorumlarını tamamladıktan sonra araştırmacıların klinik mülakat örneğine ilişkin formal raporlarını okumuşlardır. İki hafta sonunda öğretmen adaylarının gerçek yaşam bağlamlı ve belirli bir kavrama yönelik öğrenci anlamalarını değerlendirmeyi sağlayan bir soru ya da problem hazırlamaları ve bu soru doğrultusunda 
sınıflarından bir arkadaşları ile klinik mülakat gerçekleştirmeleri istenmiştir. Soru ya da problemleri hazırlamada öğretmen adayları yönlendirilmemişlerdir. Ek olarak, bu aşamada öğretmen adaylarının kavramları ve klinik mülakatı gerçekleştirecekleri arkadaşlarını kendilerinin belirlemelerine imkan verilmiştir. Bu süreçte amaç öğretmen adaylarının klinik mülakatlarındaki yaklaşımlarını incelemek ve karşılaştırmak olduğu için, uygulama aşamasında olası problemlerin önüne geçebilmek için hem mülakatı yapan hem de mülakatın yapıldığı kişinin kendisini rahat hissetmesini sağlamak için öğretmen adaylarına müdahale edilmemiştir. Öğretmen adaylarının kendi alan bilgilerinin güçlü olduğunu düşündükleri kavramları seçme eğiliminde olmaları ve bu kavrama ilişkin oluşturdukları ya da seçtikleri soruların çözümüne hakim olmaları mülakat sırasında kavram açısından süreci yönetmede problem yaşamayacaklarının gerekçesi olarak düşünülmüştür. Bu durumlar göz önüne alındığında, kavramların ve mülakatın yapıldığ 1 kişilerin farklılaşmasının çalışmanın sonuçlarını etkilemeyeceği varsayılmıştır. Ders kapsamında öğretmen adaylarının dahil oldukları işlem basamakları Tablo 2'de gösterilmektedir.

Tablo 2. Çalışmanın işlem basamakları

\begin{tabular}{lll}
\hline Basamak & Süre & Yapılan etkinlik \\
\hline 1 & 2 ders saati & Hunting (1997) makalesinin okunması \\
2 & 2 ders saati & Makale üzerine sınıf tartışmasının gerçekleştirilmesi \\
3 & 2 ders saati & Örnek klinik mülakat uygulamasının incelenmesi \\
4 & 2 ders saati & Örnek klinik mülakat uygulamasına ilişkin formal raporun okunması \\
5 & Ders dışı & $\begin{array}{l}\text { Etkinlik hazırlanması ve klinik mülakat uygulamasının } \\
\text { gerçekleştirilmesi }\end{array}$ \\
\hline
\end{tabular}

\section{Veri Toplama Aracı}

Öğretmen adayları kendi kararları doğrultusunda belirledikleri matematiksel kavram ya da kavramlara ilişkin gerçek yaşam bağlamını içeren bir soru hazırlamış ve bu soruya dayanan klinik mülakatlarını belirledikleri bir ortamda gerçekleştirmişlerdir. Öğretmen adaylarının klinik mülakatlarını iki hafta içinde tamamlayıp teslim etmeleri istenmiştir. Her öğretmen adayı bireysel olarak kendi mülakatını gerçekleştirmiş ve kamera ile kaydetmiştir. Öğretmen adaylarının klinik mülakatlarını gerçekleştirdikleri öğretmen adaylarının not ortalamaları ve mülakatta kullandıkları gerçek yaşam bağlamlı sorunun ilgili olduğu kavramlar Tablo 3’te verilmiştir. Klinik mülakatın gerçekleştirildiği öğretmen adaylarından yedisi çalışmanın katılımcısı iken, üçü çalışmada klinik mülakatları analiz edilmeyen (Katılımcı Dışı-KD) öğretmen adayıdır. 
Tablo 3. Öğretmen adaylarının klinik mülakatlarına ilişkin bilgiler

\begin{tabular}{ccc}
\hline $\begin{array}{c}\text { Mülakat1 yapan } \\
\text { ögretmen aday1 }\end{array}$ & $\begin{array}{c}\text { Mülakatın yapıldı̆̆1 öğretmen } \\
\text { adayının akademik not } \\
\text { ortalamas1 }\end{array}$ & Mülakatın yapıldığ1 kavram \\
\hline ÖA1 & 2,96 (KD1) & Olasılık \\
ÖA2 & 3,51 (ÖA1) & Türev \\
ÖA3 & 2,42 (ÖA9) & İntegral-Türev \\
ÖA4 & 2,63 (KD2) & Geometrik dönüşümler \\
ÖA5 & 2,52 (ÖA7) & Türev \\
ÖA6 & 2,35 (ÖA10) & Türev \\
ÖA7 & $3,14($ ÖA5) & Üçgende benzerlik \\
ÖA8 & 2,72 (KD3) & Binom deneyi-Olas1lı \\
ÖA9 & 3,34 (ÖA3) & Türev \\
ÖA10 & 2,56 (ÖA6) & Geometrik dizi-Limit-Türev \\
\hline
\end{tabular}

$\mathrm{Bu}$ süreçte arkadaşlarına sürekli olarak soru soran öğretmen adayları gerçekleştirdikleri klinik mülakatlarını video kamera ile kaydetmişlerdir. Öğretmen adaylarının çoğu video kamerayı kendileri temin etmiş ancak temin edemeyen öğretmen adaylarına da araştırmacılar destek olmuştur. Çalışmanın verilerini öğretmen adaylarının söz konusu klinik mülakat uygulamalarının video kayıtları oluşturmuştur.

\section{Veri Analizi}

Veri analizi aşamasında araştırmacılar ilk olarak öğretmen adaylarının klinik mülakatlarına ilişkin video kayıtlarının transkript metinlerini oluşturmuştur. Bu metinler öğretmen adaylarının sordukları sorular doğrultusunda içerik analizine tabi tutulmuştur. İçerik analizinin mülakat dökümleri, günlükler ve dokümanlar gibi genellikle metin analizini ifade ettiğini belirten Patton (2002) içerik analizinin metin içerisindeki temel tutarlılıkları ve anlamları belirlemeye yönelik herhangi bir nitel veri indirgeme ve anlamlandırma amacıyla gerçekleştirildiğini vurgulamaktadır. Çalışmada, ilk olarak öğretmen adaylarının her birinin transkript metinlerindeki soru sorma yaklaşımlarının sergilendiği bölümler belirlenmiştir. İki araştırmacı transkript metinlerinde belirlenen bölümlerdeki sorulan soruları ayrı ayrı incelemiş ve soruların sorulma amacını ve düşünceleri anlamadaki etkisini belirlemişlerdir. Sonrasında araştırmacılar bir araya gelerek, sorulan soruların amaçlarını birbirleriyle karşılaştırmışlardır. Fikir birliğine ulaşan araştırmacılar öğretmen adaylarının sorularını düşünceye odaklı sorular ve yönlendirici sorular olmak üzere temelde iki kategori altında birleştirmişlerdir (bkz. Tablo 4). 
Tablo 4. Öğretmen adaylarının klinik mülakat sırasındaki soru kategorileri

\begin{tabular}{|c|c|c|c|}
\hline $\begin{array}{l}\text { Temel soru } \\
\text { kategorileri }\end{array}$ & Alt Kategoriler & Soru örnekleri & Tanımlama \\
\hline \multirow{3}{*}{$\begin{array}{l}\text { Düşünceye } \\
\text { odaklı sorular }\end{array}$} & $\begin{array}{l}\text { Düşünceyi ortaya } \\
\text { çıkarma ve } \\
\text { genişletme }\end{array}$ & $\begin{array}{l}\text { Ne demek istedin? } \\
\text { Ne anlama geliyor? } \\
\text { Ne düşünüyorsun? }\end{array}$ & $\begin{array}{l}\text { Mülakat yapılan kişinin } \\
\text { düşüncelerini anlamaya çalışma }\end{array}$ \\
\hline & $\begin{array}{l}\text { Düşüncenin } \\
\text { adımlarını anlama ve } \\
\text { ayrıntılandırma }\end{array}$ & $\begin{array}{l}\text { Nasıl bu sonuca } \\
\text { ulaştın? } \\
\text { Nasıl bir yol izlersin? } \\
\text { Nasıl bulursun? }\end{array}$ & $\begin{array}{l}\text { Mülakat sürecini açıklanan } \\
\text { ifadeler doğrultusunda ilerletme }\end{array}$ \\
\hline & $\begin{array}{l}\text { Düşünceyi } \\
\text { gerekçelendirmeyi } \\
\text { isteme }\end{array}$ & $\begin{array}{l}\text { Neden böyle } \\
\text { düşündün? } \\
\text { Neden böyle bir yol } \\
\text { izledin? } \\
\text { Neden bunu söyledin? }\end{array}$ & \\
\hline $\begin{array}{l}\text { Yönlendirici } \\
\text { sorular }\end{array}$ & & $\begin{array}{l}\text { Bunu sağlayan koşullar } \\
\text { nelerdi? } \\
\text { Bunlar aynı şey demek } \\
\text { mi? } \\
\text { Burada dikkatini çeken } \\
\text { şeyler var mı? }\end{array}$ & $\begin{array}{l}\text { Beklenilen yanıtları almaya } \\
\text { çalışma } \\
\text { Doğrudan öncesinde amaçlanan } \\
\text { fikirlere yönlendirme } \\
\text { Süreci verilen yanıtlara göre değil } \\
\text { sonuca ulaştırma amacıyla } \\
\text { ilerletme }\end{array}$ \\
\hline
\end{tabular}

İçerik analizine dayalı olarak soru kategorileri oluşturulduktan sonra tüm öğretmen adaylarının klinik mülakat transkriptleri tekrar incelenmiştir. Öğretmen adaylarının sordukları soruların yapısına bağlı olarak ve Tablo 3'de ortaya çıkan kategoriler göz önüne alınarak her öğretmen adayının klinik mülakat boyunca sordukları soru sayısı belirlenmiştir. İlk olarak her bir öğretmen adayı için iki temel kategorideki sorular toplam soru sayısına oranlanmış ve öğretmen adaylarının sordukları soru türlerinin yüzdelik dağılımlarına ulaşılmıştır. Örneğin, ÖA1 tüm klinik mülakatı boyunca 109 düşünceye odaklı soru ve 68 yönlendirici soru olmak üzere toplamda 177 soru sormuştur. Dolayısıyla ÖA1' in \%62 (68/177) oranında düşünceye odaklı sorular ve \%38 (68/177) yönlendirici sorular sorduğu belirlenmiştir. Ardından düşünceye odaklı sorulardaki üç kategori kapsamındaki soru sayısı tüm soru sayısına oranlanarak klinik mülakat boyunca öğretmen adaylarının farklı amaçlarla sordukları soruların yüzdelik dağılımları belirlenmiştir. Örneğin, ÖA1 klinik mülakatı boyunca düşünceleri ortaya çıkarma ve genişletme amacıyla 62 soru, düşüncelerin adımlarını anlama ve ayrıntılandırma amacıyla 19 soru ve düşünceleri gerekçelendirmeyi isteme amacıyla 28 
soru sormuştur. Dolayısıyla ÖA1'in sorduğu soru dağılımlarının \%35 (62/177), \%11 $(19 / 177)$ ve \%16 (19/177) olduğu sonucuna ulaşılmıştır.

\section{Bulgular}

Öğretmen adaylarının klinik mülakatları boyunca sordukları düşünceye odaklı ya da yönlendirici soru kategorilerinin yüzdelik dağılımları karşılaştırıldığında, akademik başarı düzeyi açısından homojen gruplarda benzerlikler olmasının yanı sıra yüksek ve düşük akademik başarı düzeyi grupları açısından da bir takım benzerliklerin olduğu görülmüştür (bkz. Tablo 5).

Tablo 5. Öğretmen adaylarının klinik mülakatlarda kullandıkları soruların yüzdelik dağılımları

\begin{tabular}{cccc}
\hline \multicolumn{2}{c}{ Öğretmen adayları } & $\begin{array}{c}\text { Düşünceye odakl1 } \\
\text { sorular }\end{array}$ & Yönlendirici sorular \\
\hline \multirow{2}{*}{ Yüksek } & ÖA1 & 62 & 38 \\
akademik & ÖA2 & 55 & 45 \\
başar1 & ÖA4 & 13 & 87 \\
& ÖA5 & 48 & 62 \\
& ÖA6 & 16 & 84 \\
Düşük & ÖA7 & 10 & 90 \\
akademik & ÖA8 & 15 & 85 \\
başar1 & ÖA9 & 27 & 73 \\
& ÖA10 & 40 & 60 \\
\hline
\end{tabular}

Yüksek akademik başarı düzeyindeki öğretmen adaylarından ÖA1 ve ÖA2'nin ağırlıklı olarak düşünceye odaklı sorulardan yararlandıkları görülmüştür. Buna karşın, bu kategorideki iki öğretmen adayı (ÖA3 ve ÖA5) klinik mülakatları boyunca yüksek oranda yönlendirici sorular kategorisinde yer alan sorulardan yararlanmışlardır. Farklılaşmanın altında yatan nedenlere ilişkin ilk incelemeler, mülakatın gerçekleştirildiği kişinin akademik başarı düzeyinin bu duruma sebep olabileceğine işaret etmiştir. ÖA3 ve ÖA5’in klinik mülakatı yaptıkları öğretmen adaylarının düşük akademik başarı düzeyindeki iki öğretmen adayı (ÖA7-ÖA9) olduğu görülmüştür. ÖA7 ve ÖA9'un klinik mülakat boyunca yönelimleri incelendiğinde kendilerine yöneltilen soru için fikir üretemedikleri ve bu bağlamda ÖA3 ve ÖA5'in onları sürekli çözüme yöneltecek bağlamda sorulara başvurdukları belirlenmiştir. Ek olarak ÖA7 ve ÖA9'un bilişsel anlamda yeterli fikir üretememeleri kendilerine yöneltilen soruların da düzeyinin düşük olmasına neden 
olmuştur. ÖA3'ün klinik mülakatında sormuş olduğu yönlendirici sorularından bir kesit aşağıda verilmiştir.

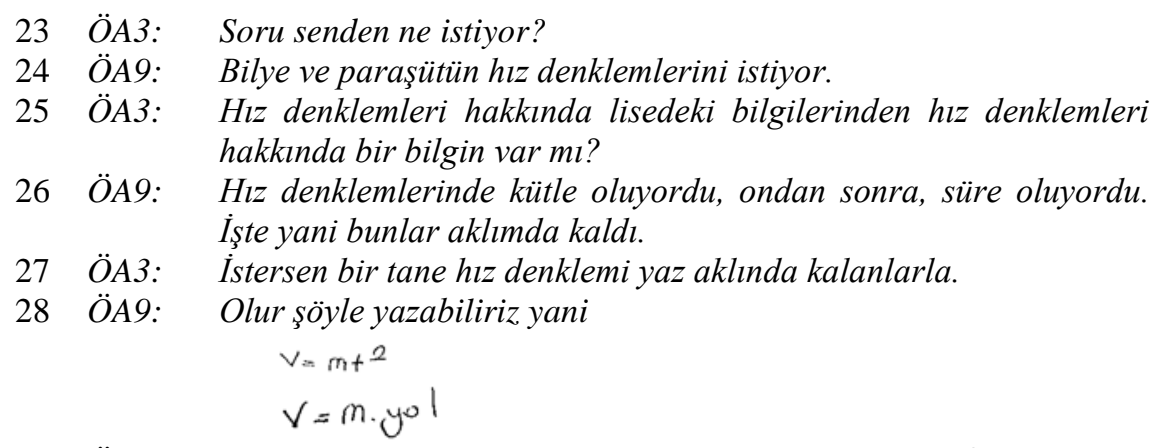

29 ÖA3: $\quad$ Bunun ikisi birbirine eşit diyebilir miyiz o zaman? $m t^{2}=m \cdot y o l$ Yolu hangi harfle simgelendirdin?

30 ÖA9: $\quad x$ olarak simgelendirdim. $m x^{\prime} i$ aslinda $m t^{2}$ şeklinde yazabiliriz

31 ÖA3: Yani $x=t^{2}$ gibi bir sonuç çıkarabilir miyiz buradan? Iki denklemi birbirine eşitlersek?

32 ÖA9: İki denklemi birbirine eşitlersek eşitliğini çıkartabiliriz. ... [Transkript metninden çıkarılan bölüm]

51 ÖA3: $\quad$ Senin birinci denklemine bakarsak günlük hayatta bir arabanın hızını belirtirken ne diyoruz?

52 ÖA9: Günlük hayatta bir arabanın hızının belirtirken mesela 70km/sa diyoruz mesela.

53 ÖA3: Yani birim olarak neyi kullanıyoruz orada?

54 ÖA9: $\quad \mathrm{km} / \mathrm{sa}$ kullanıyoruz birim olarak.

55 ÖA3: Peki senin formülünde hızın birimi ne?

56 ÖA9: Birinci bulduğumuzda kg çarpı $t^{2}$ oldu.

57 ÖA3: Ikincisinde ne oldu?

58 ÖA9: $\quad$ İkincisinde kütle çarpı kg çarpı alınan yol, $x$, oldu.

59 ÖA3: Yolun birimi ne?

60 ÖA9: $\mathrm{km} / \mathrm{sa}$.

61 ÖA3: Yolun birimi?

62 ÖA9: Yolun birimi $\mathrm{km}$.

63 ÖA3: İkisinde de birimimiz günlük hayatta kullandığımıza benziyor mu?

64 ÖA9: Benzemiyor

65 ÖA3: O zaman günlük hayatta kullandı̆̆ımıza göre bir birimimizin olması gerekir demi?

66 ÖA9: Evet öyle olması lazım

67 ÖA3: O zaman istersen birimimizi yazalım günlük hayatta kullandığımız birimimiz neydi?

68 ÖA9: $\mathrm{Km} / \mathrm{sa}$ idi.

69 ÖA3: Km neyin birimi?

70 ÖA9: $\quad K m$, alınan yolun birimi

71 ÖA3: $\quad$ Evet yazalım alınan yol diye.

72 ÖA9: Alinan yol

73 ÖA3: Peki saat neyin birimi?

74 ÖA9: Saatte geçen sürenin birimi.

75 ÖA3: $\quad$ Bu da süre.

76 ÖA9: Süre yazalım buna da

77 ÖA3: O zaman bizim hız formülümüzün ne olmasl gerekir?

78 ÖA9: $O$ zaman hız formülümüz $\mathrm{km} / \mathrm{sa}$ den düşünürsek, $V=$ alınan yol/geçen zaman diyebiliriz. 
ÖA3 “aynı kütleye sahip bir paraşütün ve çelik bilyenin h kadar yükseklikten bırakılmasıyla meydana gelen hareketin hız denklemini bulunuz." sorusu üzerine yapmış olduğu klinik mülakatta, arkadaşının soruda ne yapılması gerektiğini açıklamasını istemiştir [23]. Soruda istenileni sormak yerine arkadaşının ne anladığını ve ne düşündüğünü sorması klinik mülakatın doğasına daha uygun olurdu. Sonrasında arkadaşını doğrudan hız ile ilgili önceki bilgilerini düşünmeye ve hız denklemini hatırlamaya yönlendirmiştir [25, 27]. ÖA9 hız denklemini yazarken yol için bir değişken belirleyememiştir [28]. Sonrasında sorulunca x olarak ifade etmiş olsa da sembolün ötesinde kavramın anlamına yönelik fikirlerinin ne olduğu açık değildir. ÖA9 hız denklemi için uygun ifadeleri yazamayınca, ÖA3 hızı gerçek yaşamda nasıl örnekleyebileceğini sormuş [51] ve arkadaşının dikkatini verdiği örnek yardımıyla hızın birimine yöneltmiştir. Bu aşamada yüzeysel ve doğrudan istediği yanıtlara yönelik sorular soran ÖA3 gerçek yaşamdan örneklediği hızın birimini sormak [53] yerine verdiği hızın ne anlama geldiğini açıklamasını isteyebilirdi. Böylelikle arkadaşının hız ile ilgili sahip olduğu düşünceleri ortaya çıkarabilir ve ayrıntılandırabilirdi. ÖA9 hız ile ilgili yanlış ifadelerde bulunduğu ve hızın yol ve zaman nicelikleriyle ilişkisini hatırlamadığı için, ÖA3 hızın biriminin ne olduğu sorarak ve $v=m$. $t$ şeklinde ifade edilen hız denkleminin hatalı olduğunu fark ettirerek kendi beklediği yanıta yönlendirici yaklaşımlarda bulunmuştur. Bunun yerine, hız denklemini kütle ve zaman çarpımı olarak ifade etmesinin gerekçesini sorgulayıp arkadaşının düşüncesi üzerine klinik mülakatını devam ettirebilirdi. Ek olarak ÖA3'ün bilişsel olarak düşük eylemlere yönelten soruları [77] süreç boyunca kullandiğı belirlenmiştir. ÖA9'un üst düzey bilişsel eylemleri sergileyememesi de bu soruları sormasında etkili olmuştur.

Düşük akademik başarı düzeyindeki öğretmen adaylarının ise tamamı ağırlıklı olarak klinik mülakat sürecinde yönlendirici sorular sormuşlardır. ÖA10 ile klinik mülakat gerçekleştiren ÖA6 yönlendirici soruları en çok oranda (\%90) kullanmıştır. Türev uygulamalarından maksimum-minimum problemlerine dayalı kurguladığ gerçek yaşam problemine zemin hazırlayacak bilgileri sorarak klinik mülakatına başlayan ÖA6'nın sormuş olduğu soruları gösteren kesit aşağıda verilmiştir.

1 ÖA6: Ben soruma geçmeden önce ilk olarak bazı kavramlar ile ilgili ne biliyorsun bunu öğrenmek istiyorum. Kar nedir? Illk önce bununla başlayalım.

2 ÖA10: Kar, satı̧̧ fiyatından maliyetinin çıkartılması durumudur.

3 ÖA6: Zarar nedir? 
4 ÖA10: Zarar da, ĕger satış fiyatı maliyetinden daha düşükse zarar etmiş oluyor ve o aradaki fark da zarar oluyor.

5 ÖA6: Peki türev hakkında neler biliyorsun?

6 ÖA10: Türev de ĕgim, artışl gösteren ĕ̆im.

7 ÖA6: Hımm demek böyle diyorsun. Başka aklına neler geliyor?

8 ÖA10: Başka ne diyebilirim? [düşünüyor.]

9 ÖA6: Mesela eğim denen bir kavram var.

10 ÖA10: Ĕ̆im.

11 ÖA6: Daha sonra artanlık, azalanlık bunlar var değil mi?

12 ÖA10: Evet.

13 ÖA6: Peki o halde şimdi sorumuza başlayalım. Soru önünde yazılı zaten. Soruyu istersen oku, başlayalım sorumuza.

ÖA6 klinik mülakat için hazırlamış olduğu soruya geçmeden önce arkadaşının bu soruda yer alan kavramlarla ilgili fikirlerini sormuştur. Klinik mülakatın başında türev, kar ve zarar kavramlarına ilişkin fikirlerini sorması [1, 3, 5] ÖA10'u soruda bu kavramları kullanmaya yönlendirmiştir. Bu yaklaşımı ile arkadaşının düşünmesini sınırlandırmıştır. Eğer türev ile ilişkili kavramları ifade etmemiş olsaydı ÖA10'un türev kavramı ile ilgili ne düşündüğünü ortaya çıkarabilirdi.

Düşük akademik başarı düzeyindeki öğretmen adaylarının klinik mülakat boyunca sordukları soruların dağılımı incelendiğinde, düşünceye odaklı soruların yönlendirici sorulardan daha az oranda kullanıldığı ve hatta ÖA9 hariç düşünceye odaklı soru kullanım yüzdesinin oldukça düşük olduğu belirlenmiştir. ÖA9'un klinik mülakatı boyunca düşünceye odaklı soruları diğerlerine göre daha fazla oranda sormasında mülakatı gerçekleştirdiği ÖA3'ün yüksek akademik başarı düzeyindeki öğretmen adaylarından biri olmasının etkisi olduğu düşünülmektedir. ÖA9'un sorduğu sorulara yanıt alabilmesi ve bu sayede klinik mülakatını ilerletebilmesi ÖA3'ün düşünce üretebilmesine dayanmıştır.

Öğretmen adayları düşünceye odaklı soruları farklı amaçlar için kullanmışlardır. Tablo 6’ da öğretmen adaylarının düşünceye odaklı farklı amaçlı sorularının kullandıkları tüm sorulara göre yüzdelik dağılımları verilmiştir.

Tablo 6. Öğretmen adaylarının düşünceye odaklı soru kullanımlarının yüzdelik dağılımları

\begin{tabular}{cccc}
\hline & $\begin{array}{c}\text { Düşünceyi ortaya } \\
\text { çıkarma ve } \\
\text { genişletme }\end{array}$ & $\begin{array}{c}\text { Düşüncenin } \\
\text { adımlarını anlama ve } \\
\text { ayrıntılandırma }\end{array}$ & $\begin{array}{c}\text { Düşünceyi } \\
\text { gerekçelendirmeyi } \\
\text { isteme }\end{array}$ \\
\hline ÖA1 & 35 & 11 & 16 \\
ÖA2 & 36 & 13 & 6 \\
ÖA3 & 9 & 1 & 3 \\
ÖA4 & 24 & 17 & 7
\end{tabular}




\begin{tabular}{lccc} 
ÖA5 & 6 & 2 & 8 \\
ÖA6 & 9 & 1 & 0 \\
ÖA7 & 5 & 0 & 10 \\
ÖA8 & 15 & 6 & 6 \\
ÖA9 & 14 & 14 & 12 \\
ÖA10 & 8 & 8 & 4 \\
\hline
\end{tabular}

Öğretmen adaylarının düşünceye odaklı sordukları soruların ağırlıklı olarak düşünceleri ortaya çıkarma ve genişletme amacı taşıdığı belirlenmiştir. Klinik mülakat boyunca düşüncelerin altında yatan nedenleri ortaya çıkarmanın büyük önemi olmasına karşın, öğretmen adayları gerekçelendirme isteyen soruları diğer sorulara oranla daha az sormuşlardır. En yüksek akademik başarıya sahip ÖA1'in düşünceleri ve bu düşüncelerin gerekçelerini ortaya çıkarmaya amacıyla sorduğu sorularından bir kesit aşağıda verilmiştir.

148 KD1: A köşesinden mesela yataydaki ve dikeydeki b uzunlukları olacă̆ gibi tüm b uzunluklarl olmall.

149 ÖA1: Tüm b uzunlukları dedin. Bunu şekilde gösterir misin? Nasıl bir yer kaplar?

150 KD1: Herhangi bir b için zor bence. Mesela a/2 'ye eşit alsam yine b'yi.

151 ÖA1: Eşit almak zorunda misin?

152 KD1: Değilim ama en azından yine köşegen çizerim.

153 ÖA1: Tamam devam et.

154 KD1:

155 ÖA1: Bu çizdiğin nedir?

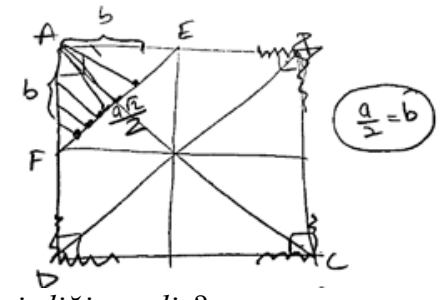

156 KD1: İsimlendireyim. E ve F olsun. Bu da EF köşegeni (dörtte birlik AEOF karesinin köşegenini çizdi.) ... [Transkript metninden çıkarılan bölüm]

174 KD1: Aslinda bu bir adet daire dilimi oldu.

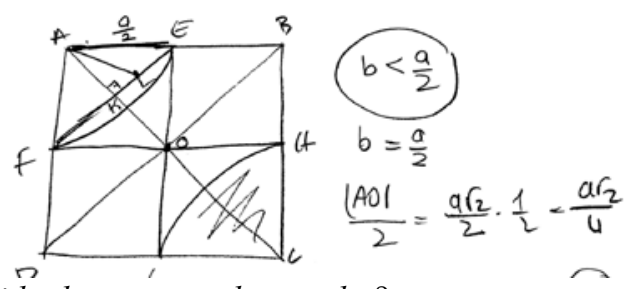

175 ÖA1: Peki bu kanıya nereden vardın?

176 KD1: Çünkü burada bir tane üçgen var.

177 ÖA1: Nasıl bir üçgen var?

178 KD1: AKE dik üçgeni.

179 ÖA1: Peki dik üçgende kenarları arasında nasıl bir ilişki var?

180 KD1: Bir dik üçgende dik açının karşısı hipotenüstür ve hipotenüs en uzun kenardir.

181 ÖA1: Neden en uzun kenardır?

182 KD1: Çünkü en büyük açıyı görüyor. Büyük açı karşısında büyük kenar vardır. Diğer açılara $\alpha$ ve $\beta$ dersem zaten toplamlarl 90 yaptığ için en büyük açı 
dik açı oluyor. Yani bizim bu AKE üçgenimizde AE en büyük kenardır. Ben $A L$ 'yi de $A E$ 'ye eşit düşünmüş̧üm.

183 ÖA1: Sen demin AL'yi de AE'yi de b birim uzunluğunda kabul etmiştin. Şuan ne düşünüyorsun?

184 KD1: Aslında AL AE'den kısa olmuş oldu. Yani benim b uzunluğumun AL'yi geçmesi lazım.

ÖA1, bir kenarı a birim olan düzgün beşgen şeklindeki bir hedefe ok atıldığını ve okların hedefin köşelerinden en az b birim uzaklığa isabet ettirildiği an puan alınan bir oyunun kazanılma olasılığını sormuştur. Bu soru üzerinde düşünen KD1, ilk olarak hedefi kare olarak çizmiş ve karenin üzerinde yorumlayarak daire dilimlerinin oluştuğu sonucuna ulaşmıştır [148]. ÖA1 öncelikle arkadaşının düşüncelerine odaklanarak süreçteki adımlarını ayrıntılandırmak için "Bu kanıya nereden vardın?/Bu çıkarıma nasıl ulaştın?" sorusunu yöneltmiştir. Bu diyalogun devamında hipotenüsün en uzun kenar olduğunu ifade eden arkadaşına bu ifadesinin gerekçesini sorarak açıklamasını istemiştir. Süreç içerisinde KD1 soru üzerinde düşündükçe fikirlerini değiştirmiş ve kendi çıkarımlar yapmaya başlamıştır. ÖA1 arkadaşının düşüncelerindeki farklılığı göz önüne alarak ne düşündüğünü sorgulamıştır [183]. Verilen kesitte görülebileceği gibi, ÖA1 klinik mülakatında arkadaşının düşüncelerine odaklanarak sorduğu soruları onun söylemlerine göre şekillendirmiştir.

Diğer öğretmen adaylarıyla karşılaştırıldığında klinik mülakatında ağırlıklı olarak düşünceye odaklı sorular soran bir diğer öğretmen adayı olan ÖA2'nin türev uygulamaları üzerine gerçekleştirdiği klinik mülakatından bir kesit aşağıda verilmiştir:
44 ÖA1:
Şu anda verdiğim sayllara göre hacmi hesaplamak istiyorum.
45 ÖA2:
$x=40 y=30 z=20$ ise $40 \cdot 30 \cdot 20=24000 \mathrm{~cm}^{3}$ olur.
46 ÖA1:
Neden böyle bir yol izledin?
Bana böyle bilgiler verilmişti. $x+y+z=90$ olduğunu benden en
büyük hacim isteniyordu. Bende boyutlara farklı farklı değerler vererek
hacmini hesaplayacağım. Bana bir çağrlşım yapabilir diye hacmini hesaph
düşünüyorum.
47 ÖA2: Devam edebilirsin.
48 ÖA1: 3 boyutu farklı vermiştim. Bu sefer x'i değiştirmeyip y ve z'yi eşit alayım.
49 ÖA2: Neden y ve z'yi eşit almayı düşünüyorsun?
50 ÖA1: $\quad$ Biraz önce farkll almıştım şimdi eşit alırsam ne değişecek onu görmek istiyorum. $x$ en büyük boyuta sahip. $y=25 \mathrm{~cm}, z=25 \mathrm{~cm}$ alayım $x$ ' $i$ değiştirmeyip gene $x=40 \mathrm{~cm}$ alırım. (işlemini yapllyor kontrol ediyor.) $x \cdot y \cdot z=25 \cdot 25 \cdot 40=25000 \mathrm{~cm}^{3}$ buldum.
51 ÖA2: Nasil bir çıkarımda bulundun?
52 ÖA1: Şöyle bir çıkarımda bulundum. Değerler birbirine yakınlaştıkça hacmin büyüdüğ̈̈nü gördüm. Bu sefer hepsini eşit alayım hatta. Az önce ikisini eşit almıştım. Şimdi hepsini eşit alayım. ... [Transkript metninden çıkarılan bölüm] 
169 ÖA1: $\quad H=\pi r^{2} . b$ Benden bulmamı istediği şey. Yine tek bilinmeyen lazım ama şuanda da hem $r$ hem $b$ bilinmeyeni var. $b+4 r=104$ denklemini kullanarak r'yi çekebilirim.

r'yi çekeyim. $4 r=104-b$

$$
r=104 / 4-b / 4
$$

170 ÖA2: $\quad$ Daha farkl bir çözümle gidebilir misin? Rasyonel olmayan

171 ÖA1: $\quad$ r'yi rasyonel buldum. Karesini alacă̆ım zor olacak benim için.

172 ÖA2: $\quad$ Işsine yarayacak şekilde farkl alternatif çözüm üretebilir misin?

173 ÖA1: Evet doğru, o zaman ben r'yi değil de b'yi çekeyim. b=104-4r olacak $b$ 'yi çekmem daha çok işime yarad. Hacim dediğim şey $H=$ $\pi r^{2} \cdot(104-4 r)$ yazllabilir. Şimdi gene türevini alıyorum ve sıfıra eşitleyeceğim.

174 ÖA2: $\quad$ Seni buna iten şey ne oldu?

175 ÖA1: CCünkü türevini sıfira eşitliyorduk.

176 ÖA2: Neden?

177 ÖA1: $\quad$ Maksimum, minimum noktaları bizim için türevin slfir olduğu yerler.

178 ÖA2: $\quad$ Nasll böyle bir düşünceye vardın? Gösterebilir misin?

179 ÖA1: Maksimum hacmini bulmak için az önceki soruda da onu yapmıştım

180 ÖA2: $\quad$ Maksimum, minimum noktalart nasll belirliyoruz?

181 ÖA1: Şekil üzerinde gösterebilirim aslında.

182 ÖA2:

183: ÖA1:

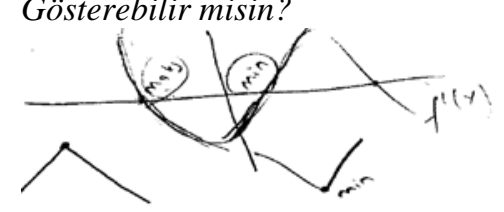

(Grafik üzerinde noktaları gösteriyor.) Bu noktalar benim için minimum ve maksimum noktalardır.

Verilen kesit incelendiğinde, ÖA2, ÖA1 ile yapmış olduğu klinik mülakatta, arkadaşının düşüncelerini ortaya çıkarmak ve genişletmek için, "Nasıl bir çıkarımda bulundun? [51]", "Seni buna iten şey ne oldu? [174]" gibi soruların yanı sıra düşüncelerinin adımlarını ayrıntılandırmasını isteyen "Nasıl böyle bir düşünceye vardın? Gösterebilir misin? [178]” gibi sorular da sormuştur. Ek olarak, ÖA2'nin arkadaşının yaptıklarının gerekçesini ortaya çıkarmak için "Neden böyle bir yol izledin? [45]”, “Neden y ve z'yi eşit almayı düşünüyorsun?” [49], "Neden sıfıra eşitliyorduk? [175-176]” gibi sorular yönelttiği görülmüştür.

Düşük akademik başarı düzeyindeki öğretmen adaylarından ÖA8 binom deneyi ve olasılık konusunda "Bir firma tarafından üretilen stres çarklarının \%5'inin kusurlu (arızalı) olduğu bilinmektedir." ifadesini vererek "Bu firmada üretilen stres çarklarının rassal 3 tanesinin seçilmesi ve kalite kontrol uzmanlarınca dikkatli bir şekilde incelenmesi deneyi, bir binom deneyi midir?" ve "Rastgele seçilmiş olan 3 stres çarklarının sadece bir tanesinin arızalı olma olasılığı nedir?” soruları üzerine klinik mülakatını yürütmüştür. Klinik mülakatında ağırlıklı olarak (\%73) yönlendirici sorular sormuş ancak yine de 
düşünceye odaklı sorularla arkadaşının düşüncelerini anlamaya çalışmıştır. Aşağıda ÖA8'in mülakatından bir kesit verilmiştir.

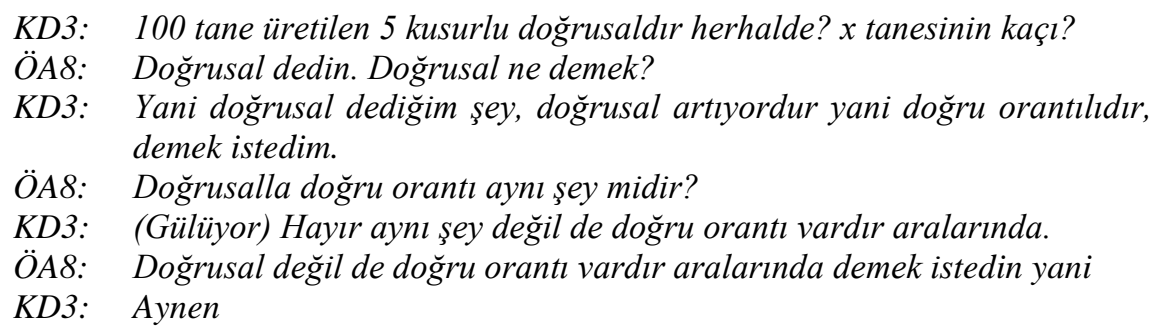

KD3'ün verilen ifadeyi doğrusal bir ilişki olarak yorumlaması üzerine ÖA8 "Doğrusal ne demek? [2]” sorusunu yönelterek arkadaşının düşüncesini anlamaya çalışmıştır. Ancak devamında beklediği yanıtı alamayınca KD3'ün ifadesinde düzeltmeye gitmiş, kendisi açıklama yapmış ve onu sonuca yönlendirmiştir.

\section{Tartışma, Sonuç ve Öneriler}

Yüksek ve düşük başarı düzeyindeki matematik öğretmeni adaylarının gerçekleştirdikleri klinik mülakatların karşılaştırıldığı bu çalışmada, iki gruptaki öğretmen adaylarının klinik mülakatları süresince sordukları soruların farklılaştığı görülmüştür. Bu farklılıklar hem katılımcıların oluşturduğu iki kategori arasında hem de kategorilerin kendi içerisinde karşımıza çıkmaktadır. Yüksek akademik başarıya sahip öğretmen adayları ağırlıklı olarak "Neden?" "Nasıl?”, "Ne düşünüyorsun?” gibi düşüncelere odaklanan sorular sorarken, düşük akademik başarı düzeyindeki öğretmen adayları ise genellikle sonuç odaklı yönlendirici sorulardan yararlanmışlardır. Aynı zamanda düşüncelere odaklanan soruları yönlendirici sorulara oranla daha fazla kullanan üç öğretmen adayının etkili klinik mülakatlar yapabildikleri sonucuna ulaşılmıştır. Klinik mülakatın düşünceleri ve altında yatan sebepleri ortaya çıkarmak amacıyla yapıldığı göz önüne alındığında, düşük akademik başarı düzeydeki öğretmen adaylarının sordukları düşüncelere odaklı olmak yerine sonuca odaklı olduğu için etkili klinik mülakatlar gerçekleştiremedikleri söylenebilir. Buna karşın, Groth, Bergner ve Burgess (2016) dört matematik öğretmen adayının klinik mülakatını incelemeye yönelik gerçekleştirdikleri çalışmalarında içerik ve öğrenci bilgisinin klinik mülakat süresince anlık sorular oluşturmada rol oynadığını ifade etmekle birlikte bu bilgilerin klinik mülakat için ön gereklilik olmadığını da belirtmişlerdir. Çalışmamızın bulgularına dayalı olarak etkili bir klinik mülakat yaparken sorulan sorular için öğretmen adaylarının alan ve alan öğretimi 
bilgilerinin belirleyici etkenler olduğu düşünülmektedir. Çünkü öğretmen adaylarının ya da öğretmenlerin ilgili kavramlara ilişkin yeterli bilgileri yoksa ve bu eksikliklerinin farkında iseler o kavram ile ilgili öğrencilerin fikirlerini sorgulamaktan kaçınmaktadırlar. Bunu destekler şekilde, Son ve Sinclair (2010) öğretmen adaylarının öğrencilerin düşüncelerine yanıt verebilmeleri için alan bilgilerinin ötesinde alan öğretimi bilgilerinin güçlü olması gerektiğini ifade etmişlerdir. $\mathrm{Bu}$ çalışmada, öğretmen adaylarının arkadaşlarının fikirlerini ön görememeleri, mülakat sırasında beklenmeyen düşüncelerle karşılaşmaları ve bu durumlara yönelik hazırlıksız olmaları da soru sorma becerilerini etkileyen bir faktör olarak karşımıza çıkmaktadır. Öğretmen adaylarının soruları, arkadaşlarının düşüncelerini sesli olarak ifade etmelerini tetiklediği için klinik mülakatın etkili bir şekilde gerçekleştirilmesinde rol oynamıştır. Buna paralel olarak, Ashlock (2006) klinik mülakat sürecinde öğrencilerin sesli düşünmelerini sağlayacak yaklaşımlarda bulunmanın önemli bir etken olduğu ifade etmiştir. İleriki çalışmalarda öğretmen adaylarının klinik mülakat öncesinde kavramın yapısını daha iyi ayrıntılandırma, kavramın içerdiği ve ilişkili olduğu fikirleri ortaya çıkarma ve olası öğrenci düşüncelerini tahmin etme gibi çalışmaları içeren kavramsal analiz sürecini gerçekleştirmeleri ve kavramsal analizlerine dayalı klinik mülakatlar gerçekleştirmeleri istenebilir. Ardından yaptıkları klinik mülakatlar analiz ettirilerek kendi mülakat süreçlerini derinlemesine inceleme ve kendilerini değerlendirmeleri sağlanabilir. Böylelikle alan, alan öğretimi ve özellikle öğrenci düşüncesi bilgileriyle birlikte soru sorma becerileri doğrultusunda klinik mülakatlarının gelişimleri desteklenebilir. Ek olarak, öğretmen adaylarının klinik mülakat sürecinde ilgili kavrama ilişkin derin kavramsal bilgilerinin de etkili olduğu düşünülmektedir. Kavrama ilişkin bilgilerindeki eksiklikleri de süreci yönetememelerine yol açmış olabilir. Dolayısıyla alan ve alan öğretimi bilgisinin yanı sıra klinik mülakatın yapıldığı kavramlara ilişkin kavramsal bilgilerinin güçlendirilmesine yönelik çalışmalar yapmaları istenebilir.

Kategoriler arası farklılıkların yanı sıra benzerliklerin de ortaya çıktığı görülmüştür. Her iki grupta mülakatı yapan öğretmen adayları, süreçte sordukları sorulara arkadaşlarının yanıt verememeleri üzerine onları sorgulamaya devam edememişlerdir. Klinik mülakat kavramlar hakkında bilgisi olmayan ve kavramları öğrenememiş bireylerin süreç boyunca nasıl düşündüklerini ortaya çıkarmak için etkili bir yol olmasına karşın klinik mülakatı gerçekleştiren öğretmen adayları hiçbir yanıt alamamaları halinde 
klinik mülakatın ilerleyen aşamalarında sonuç odaklı ve yönlendirici sorular sormaya yönelmişler ve bu da arkadaşlarının düşüncelerini ortaya çıkaramamalarına neden olmuştur. Bu süreçte düşük akademik başarı düzeyindeki öğretmen adaylarının belirlenmiş problem durumları üzerinde akıl yürütememiş olmaları öğretmen adaylarının arkadaşlarının düşüncelerine ulaşamamalarına yol açmış olabilir. İleriki çalışmalarda problem durumlarının klinik mülakat sürecine olan etkileri incelenebilir. Hunting (1997) mülakatı gerçekleştiren kişinin yorum yapmasına yardımcı olmak için yeterli veri mevcut değilse, daha sonra alternatif bir etkinlik ya da problem durumundan yararlanılabileceğini ifade etmiştir.

Bu sonuçlara ek olarak, düşük akademik başarı düzeyindeki bir öğretmen adayı yüksek akademik başarı düzeyindeki bir öğretmen adayı ile klinik mülakat gerçekleştirirken düşüncelere odaklı soruları bir ölçüde kullanabilmiştir. Dolayısıyla, düşük akademik başarıdaki öğretmen adaylarının yüksek akademik başarıdaki öğretmen adaylarıyla klinik mülakat yapmalarının onları destekleyeceği söylenebilir. Her ne kadar çalışmada mülakatın yapıldı̆̆ı kişinin akademik başarısına odaklanılmış olsa da mülakatın yapıldığı kişinin de akademik başarısının önemli olabileceğine ilişkin bulgular bu durumun daha sistematik bir şekilde ele alınması ve daha ayrıntılı bir şekilde incelenmesi ile desteklenebilir. Ayrıca çalışma, öğretmen adaylarının iki haftalık süre kapsamında oluşturulan içeriğe katılımları sonrasında gerçekleştirdikleri klinik mülakatlarına dayandırıldığı için sınırlılık oluşturmaktadır. Bu sebeple öğretmen adaylarının ve öğretmenlerin uzun dönemli klinik mülakat çalışmalarına dahil edilmelerinin ardından gerçekleştirecekleri klinik mülakatları incelenip onlara dönütler sunularak gelişimleri sağlanabilir.

\section{Makalenin Bilimdeki Konumu}

Matematik ve Fen Bilimleri Eğitimi/Matematik Eğitimi

\section{Makalenin Bilimdeki Özgünlüğü}

Klinik mülakat, matematik eğitiminde kullanılan yaygın bir yöntem olmakla birlikte Türkiye’de genellikle araştırma yöntemi olarak karşımıza çıkmaktadır. Bu çalışma matematiği öğretme ve öğrenme sırasında klinik mülakatın kullanılmasına ilişkin bir örnek sunmaktadır. Farklı akademik başarıların klinik mülakatı gerçekleştirme sürecine yansımalarını gösteren bulgular, öğretmen eğitimindeki öğretim süreçlerinin ve 
içeriğinin geliştirilmesi gerekliliğini ortaya çıkarmaktadır. Klinik mülakatın hem matematik eğitiminde neden önemli olduğunu ve öğrenme-öğretme sürecine nasıl entegre edilebileceğine yönelik bir bakış açısı sağlamakta hem de uygun ve uygun olmayan klinik mülakat kesitleriyle bu sürecin nasıl yürütülebileceğini göstermektedir. Ayrıca mülakatta kullanılan problemlerin ve etkinliklerin rolü, süreci yönetme, mülakattaki bireylerin rolleri ve soru sorma gibi açılardan klinik mülakat üzerine bir tartışma ortamı oluşturarak etkili klinik mülakatlar gerçekleştirmede fikirler sunmaktadır.

\section{Kaynaklar}

Adams, T. L. (1998). Alternative assessment in elementary school mathematics. Childhood Education, 74(4), 220-224.

An, S., \& Wu, Z. (2012). Enhancing mathematics teachers' knowledge of students' thinking from accessing and analyzing misconceptions in homework. International Journal of Science and Mathematics Education, 10(3), 717-753.

Ashlock, R. B. (2006). Error patterns in computation: Using error patterns to improve instruction (9th ed.). Upper Saddle River, NJ: Pearson.

Bowman, B. T., Donovan, S., \& Burns, M. S. (2000). Eager to learn: Educating our preschoolers. Washington, DC: National Academies Press

Carpenter, T.P., Fennema, E., \& Franke, M.L. (1996). Cognitively guided instruction: A knowledge base for reform in primary mathematics instruction. Elementary School Journal, 97(1), 3-20.

Clement, J. (2000). Analysis of clinical interviews: Foundation and model viability. In A. E. Kelly \& R. Lesh (Eds.), Handbook of research design in mathematics and science education (pp. 547-589). New Jersey: Lawrence Erlbaum.

Common Core State Standards Initiative [CCSSI]. (2010). The common core state standards for mathematics. Washington, DC: National Governors Association Center for Best Practices and Council of Chief State School Officers.

Confrey, J. (2006). The evolution of design studies as methodology. R. K. Sawyer (Ed.), The Cambridge Handbook of the Learning Sciences (pp.135-152). New York, NY: Cambridge University Press.

Creswell, J. (2013). Araştırma deseni: Nicel, nitel ve karma yöntem yaklaşımları (Çev. S. B. Demir) Ankara: Eğiten Kitap Yayınları. (Orijinal yayın tarihi, 2013) 
Engelhardt, P. V., Corpuz, E. G., Ozimek D. J. \& Rebello, N. S. (2004). The teaching Experiment -What it is and what it isn't? Proceedings of Physics Education Conference-AIP Conference (pp. 157-160). Madison, WI.

Ernest, P. (1993). Constructivism, the psychology of learning, and the nature of mathematics: Some critical issues. Science \& Education, 2(1), 87-93.

Fuchs, E., \& Czarnocha, B. (2016). Teaching research interviews. In B. Czarnocha, W. Baker, O. Dias, \& V. Prabhu (Eds.) The creative enterprise of mathematics teaching research: Elements of methodology and practice-from teachers to teachers (pp.179-198). Rotterdam, Netherlands: Sense Publishers.

Ginsburg, H. (1981). The clinical interview in psychological research on mathematical thinking: Aims, rationales, techniques. For the learning of mathematics, 1(3), 411.

Ginsburg, H. (1997). Entering the child's mind: The clinical interview in psychological research and practice. Cambridge: Cambridge University Press.

Ginsburg, H. P., Jacobs, S. F., \& Lopez, L. S. (1993). Assessing mathematical thinking and learning potential. In R. B. Davis \& C. S. Maher (Eds.), Schools, mathematics, and the world of reality (pp. 237-262). Boston: Allyn \& Bacon.

Haydar (2017). Elementary teachers and students talking algebra: The clinical interview and children's algebraic reasoning. In Proceedings of ICERI2017, November 2017, Seville, Spain.

Heirdsfield, A. (2002). The interview in mathematics education: The case of mental computation. In Annual Conference of the Australian Association for Research in Education, December 2002, Brisbane, Australia.

Hunting, R. P. (1997). Clinical interview methods in mathematics education research and practice. Journal of Mathematical Behaviour, 16(2), 145-165.

Jenkins, O. F. (2010). Developing teachers' knowledge of students as learners of mathematics through structured interviews. Journal of Mathematics Teacher Education, 13, 141-154.

Kazemi, E., Gibbons, L. K., Lomax, K., \& Franke, M. L. (2016). Listening to and learning from student thinking. Teaching Children Mathematics, 23(3), 182-190.

Ginsburg, H. P., Jacobs, S. F., \& Lopez, L. S. (1993). Assessing mathematical thinking and learning potential in primary grade children In M. Niss (Ed.), Investigations 
into assessment in mathematics education: An ICMI study (pp. 157-167). Dordrecht: Kluwer Academic Publishers.

Koichu, B., \& Harel, G. (2007). Triadic interaction in clinical task-based interviews with mathematics teachers. Educational Studies in Mathematics 65(3), 349-365.

Mojica, G. (2010). Preparing pre-service elementary teachers to teach mathematics with learning trajectories. Yayınlanmamış doktora tezi. North Carolina State University, USA.

Moyer, P.S. \& Milewicz, E. (2002). Learning to question: Categories of questioning used by preservice teachers during diagnostic mathematics interviews. Journal of Mathematics Teacher Education, 5, 293-315.

National Council of Teachers of Mathematics. (2000). Principles and standards for school mathematics. Reston, VA: Author.

Pablopulos, A. \& Carolina, C. (2015). Investigating the use of the clinical interview method in an elementary mathematics methods course, Yayınlanmamış doktora tezi. Rutgers University, Graduate School of Education, New Jersey, USA.

Son, J., \& Sinclair, N. (2010). How preservice teachers interpret and respond to student geometric errors. School Science and Mathematics, 110(1), 31-46.

Taylan, R. D. (2018). Exploring prospective teachers' reflections in the context of conducting clinical interviews. European Journal of Educational Research, 7(2), 349-358.

van den Kieboom, L., Magiera, M. T., \& Moyer, J. (2017). Learning to notice student thinking about the equal sign: K-8 pre-service teachers' experiences in a teacher preparation program. In E. O. Schack, M. H. Fisher, \& J. Wilhelm, (Eds.), Teacher noticing - Bridging and broadening perspectives, contexts, and frameworks, (pp. 141-159). New York, NY: Springer.

Weiland, I. S., Hudson, R. A., \& Amador, J. M. (2014). Preservice formative assessment interviews: The development of competent questioning. International Journal of Science and Mathematics Education, 12(2), 329-352. 


\section{Summary}

\section{Statement of Problem}

In the report of National Council of Teachers of Mathematics (NCTM, 2000) it is emphasized that the assessment, one of the six principles for school mathematics, should support the learning of important mathematics and present useful information to both teachers and students (p.22). The conventional assessment approaches are not adequate for evaluate students' understanding, and teaching and learning process needs the alternative assessment approaches which provide teachers to attain more detail information about the students and focused on learning process rather than outputs (Ginsburg, Jacobs, \& Lopez, 1993; Kazemi, Gibbons, Lomax, \& Franke, 2016). In recent years, one of the alternative assessment approaches used in the mathematics education is clinical interview. According to Piaget, the aim of a clinical interview is to reveal children's ideas, pre-existing schemes, mental tendency and intellectual habits (Confrey, 2006). Ginsburg (1981) has emphasized three purposes of clinical interview. The first purpose is to explore students' cognitive processes, second one is to define the basis of their cognitive processes and the last one is to determine students' abilities. Since the main aim of the mathematics teaching is to identify students' forming constructs during the mathematics learning process, using the clinical interview for assessment is of importance. So, the opportunities related to the clinical interview in the context of teacher education programs are necessary for prospective mathematics teachers. The question of whether prospective mathematics teachers who have well content and pedagogical content knowledge will conduct more effective clinical interview brings up. Hunting (1997) has also stated that pedagogical content knowledge is necessary for a clinical interview skill. The aim of the study was to investigate how the prospective mathematics teachers' content and pedagogical content knowledge would reflect in their clinical interviews. In addition, it was aimed to determine the needs of prospective teachers based on the evidences while conducting clinical interviews. In the study, the prospective teachers' academic averages were taken into consideration for their content and pedagogical content knowledge and considered as the level of academic success. Determining how prospective teachers' success levels are reflected in the clinical interview process will provide evidence for the relationship between clinical interview and content and pedagogical content knowledge. This relationship can be revealed more 
effectively by focusing on the clinical interview practices of prospective teachers at different academic levels and comparing them with each other. In this direction, the aim of this study is to compare the clinical interviews realized by the prospective teachers having different academic achievements.

\section{Method}

This study was conducted by embedded multiple case study. The participants of this case study were ten mathematics prospective teachers selected by stratified purposeful sample. The selection of participants was based on their grade point average. Five had the highest academic averages while the others had the lowest academic averages. The prospective teachers attended to the teaching method course including the clinical interview practices during two weeks. At the end of the semester, they were asked to form a clinical interview protocol including a question in a real life context and to make the interview with his/her friend. The data were the video recordings of the clinical interview conducted by the prospective teachers. Each video recordings were transcribed verbatim and the transcripts were analysed in the context of questions asked by the student teachers.

\section{Findings and Discussions}

The prospective teachers asked focusing and leading questions during the clinical interviews. While the prospective teachers with higher academic achievement generally asked the focusing questions such as "What do you think?”, "Why do you think so?”, "Which ways do you follow?", the prospective teachers with lower academic achievement asked funneling and result-oriented questions. Considering that clinical interviews are conducted to reveal the thoughts and the underlying reasons, it can be said that prospective teachers with low academic achievement could not conduct effective clinical interviews because they were focused on the results rather than interviewee's thinking. Son and Sinclair (2010) stated that prospective teachers should have strong pedagogical content knowledge as well as content knowledge in order to respond to students' thoughts.

Also, two prospective teachers having high success asked the funneling questions during the clinical interviews. The reason of this difference could be that these 
prospective teachers made the interview with the prospective teachers having low achievement. In this process, the interviewer could not reach the ideas of their friends because the prospective teachers with low academic achievement could not think the problem situations. Hunting (1997) has stated that if there is not enough data for the interviewer to evaluate the thoughts of interviewee, it can be used another alternative problem situation and a task. In addition to these results, a prospective teacher at a low level of academic achievement was able to use focusing questions at the least when conducting a clinical interview with a prospective teacher having high academic success. Therefore, it can be said that pre-service teachers having low academic success will conduct clinical interviews with pre-service teachers having high academic success and this process can support them.

The prospective teachers' questions differenced accordance with the student prospective teachers' content and pedagogical content knowledge. On the other hand, conducting the clinical interviews and examining these interviews could improve prospective teachers' knowledge. Also, Jenkins (2010) has stated that clinical interviews are effective for prospective teachers in improving their content and student knowledge because these processes give opportunities them to observe students' thinking.

\section{Conclusions and Recommendations}

Based on the findings, the prospective teachers' academic successes were an important factor for their questions during the clinical interview. Because, prospective teachers or teachers avoid questioning students' ideas if they do not have enough strong knowledge about concepts and are aware of their own deficiencies. Also, the fact that they cannot foresee students' ideas and they face with unexpected student thoughts emerges as the factors affecting their abilities to ask questions. So, presenting different clinical interview practices to prospective teachers and discussing these interviews with them is important in teacher education. Additionally, it is thought that the prospective teachers having different academic successes conduct the clinical interviews with each other will support their professional development. 